\title{
Physiographic influences on dense shelf-water cascading down the Antarctic continental slope
}

\author{
D. Amblas* and J.A. Dowdeswell \\ Scott Polar Research Institute, University of Cambridge, Lensfield Road, Cambridge CB2 1ER, UK \\ *Corresponding author
}

\begin{abstract}
Predicting the source areas for Antarctic Bottom Water (AABW) requires knowledge of how cold, dense water masses form and move from the Antarctic shelves to the continental slope. Here we use a review of nearly 50 years of direct hydrographic observations to infer the main broad-scale influences on the distribution of dense shelf-water (DSW) overflows that cascade down the continental slope around Antarctica. The dynamics and distribution of large ice shelves, coastal polynyas and the physiography of the Antarctic continental shelves are each considered. The catalogue we present increases the number of DSW observations to 27, adds 20 additional stations where this process is likely to have occurred, and identifies 41 areas where DSW appears to be absent. Our pan-Antarctic, multi-decadal review enhances the understanding of the formation and export of DSW and highlights the variability and complexity of ice-ocean systems on high-latitude continental margins. The study also provides a context for understanding recent episodes of Antarctic ice-shelf instability, and how the relationship between DSW and AABW may evolve with climatic and oceanographic changes.
\end{abstract}

\section{Introduction}

The downslope transport of dense shelf-water (DSW) plays an important role in Earth's climate system and biogeochemical cycles (Ivanov et al., 2004; Shapiro, 2003). In Antarctica, cold DSW overspills the continental shelf and cascades down the slope as an underflow that becomes Antarctic Bottom Water (AABW), a major component of the global deep-ocean circulation (Baines and Condie, 1998; Jacobs, 2004; Orsi et al., 1999). The primary mechanism for DSW generation over the Antarctic continental shelf is enhanced sea-ice production and consequent salt-rejection in recurrent coastal polynyas (Jacobs et al., 1970). These virtually ice-free zones are generated by a combination of strong katabatic winds and physical barriers that block the inflow of sea ice and allow its continuous production, mainly during autumn and winter (Morales Maqueda et al., 2004; Nicholls et al., 2009). Ice-ocean interactions at the base of floating ice-sheet fed ice shelves also represent a substantial source of DSW, although this source is generally colder, fresher and less dense than that produced in polynyas (Foster and Carmack, 1976; Jacobs et al., 1970).

DSW formation around Antarctica has been studied extensively by physical oceanographers for several decades. The first comprehensive catalogue of DSW cascades from the shelf down the continental slope around Antarctica, also known as DSW overflows, was presented by Baines and Condie (1998). Killworth (1983) had made a similar survey several years before but mainly focused on open-ocean deep convection areas. Ivanov et al. (2004) added several additional observations to the inventory by Baines and Condie (1998). Yet, despite the increasing number of DSW cascade studies and advances in observational techniques, these compilations have not been significantly 
updated since their publication. Our study therefore represents the first expanded, up-to-date review of modern DSW cascades in over a decade. We report observations spanning the circum-Antarctic continental slope (Fig. 1 and Table 1), addressing both the presence and absence of DSW in varying oceanographic and physiographic settings.

Comprehensive mapping of coastal polynyas and sea-ice production (Fig. 1) is now possible using advanced processing of satellite microwave radiometer data. The resulting maps reveal areas of open water and thin sea ice, the latter even in winter conditions when polynyas show little surficial expression (Nihashi and Ohshima, 2015; Ohshima et al., 2016, 2013, Tamura et al., 2016, 2008). These inferred polynyas are found along the continental shelf around Antarctica, although only a few show conditions favourable for the generation of DSW cascades and the production of AABW (Ohshima et al., 2016; Orsi et al., 1999).

The Weddell Sea and Ross Sea are considered to be the main producers of AABW (Orsi et al., 2002). In addition to large ice shelves and highly productive polynyas - especially in the Ross Sea - both regions exhibit deep and wide continental shelves with large cross-shelf depressions that have the capacity to accumulate and export large volumes of DSW (Foldvik et al., 2004; Gordon et al., 2004; Killworth, 1983; Livingstone et al., 2012). More recently, new areas capable of exporting DSW to form AABW have been identified along narrower continental shelves with more limited storage capacity, such as the regions off the Adélie Coast (Williams et al., 2016, 2008), Prydz Bay (Yabuki et al., 2006) and Vincennes Bay (Kitade et al., 2014) in East Antarctica (Fig. 1). These areas, which together may generate an appreciable fraction of AABW (Ohshima et al., 2016), bring into question the dominant role that shelf storage plays in generating sufficient negative buoyancy for DSW export. This question is addressed here through a thorough study of Antarctic continental-shelf physiography.

\subsection{Observations of DSW cascades}

Before the advent of modern instruments to measure conductivity/salinity and temperature continuously with depth (CTDs) in the late 1960s, DSW flows were scarcely observed in-situ, due mainly to the fact that they rarely exceed 300-400 $\mathrm{m}$ in vertical thickness (Baines and Condie, 1998; Budillon et al., 2002; Ohshima et al., 2013). The first observations of active DSW flows down Antarctic slopes were made during the late 1960s and early 1970s in the southern Weddell Sea (Foster et al., 1987; Foster and Carmack, 1976; Seabrooke et al., 1971) and in the Ross Sea (Gordon, 1975; Gordon et al., 2015; Jacobs et al., 1985, 1970; Smith Jr et al., 2012). In 1974 a cascade event in East Antarctica was first monitored at the shelf break $370 \mathrm{~km}$ north of Prydz Bay (Jacobs and Georgi, 1977). During the early 1990s new studies also confirmed the presence of DSW cascades in the Larsen C region of the northwestern Weddell Sea (Fahrbach et al., 1995; Muench and Gordon, 1995) and later and more recently in the d'Urville Sea, near Mertz Glacier (Fukamachi et al., 2000; Snow et al., 2018). More recently, additional discoveries have taken place mainly in East Antarctica, in areas including Prydz Bay (Ohshima et al., 2013; Williams et al., 2016), Vincennes Bay, and off the Wilkes Land coast (Kitade et al., 2014).

The Antarctic DSW catalogue of Baines and Condie (1998) was based on published and unpublished cross-slope temperature and salinity sections, all derived from CTD casts. Of the 59 hydrographic sections reviewed, 12 documented positive evidence of DSW cascade occurrence, 27 showed no evidence at all, and 20 showed indirect evidence of DSW cascades with near-bottom water densities and temperatures suggesting recently active flows and/or flows adjacent to the site of measurement. Baines and Condie (1998) named these three types of observations as A (Active), $\mathrm{N}(\mathrm{Nil})$ and $\mathrm{P}$ 
(Passive), respectively. In this paper we use their terminology. For obvious logistical reasons most of these observations belonged to the austral summer and autumn seasons (December-May), whereas downslope flows tend to be more frequent (and thus observable) in winter when the offshore-directed katabatic winds drained from the continent are generally stronger and colder (Baines and Condie, 1998; Lacarra et al., 2014). The first winter CTD observations were made during challenging icedrifting surveys that lasted several months including the freezing midwinter period (Gordon, 1993; Muench and Gordon, 1995). More recently, the deployment of moored instruments (CTD, ADCP, current meters) at specific sites along the Antarctic margin has provided year-round, continuous measurements (Jensen et al., 2013; Ohshima et al., 2013; Williams et al., 2016), adding valuable information on the variability and magnitude of DSW cascades and their relationship to atmospheric, oceanographic and cryospheric forcing. Another recent source of measurements has come from seals fitted with instruments, providing hydrographic data in what would otherwise be inaccessible regions and seasons (Kitade et al., 2014; Ohshima et al., 2016).

The worldwide inventory of DSW cascades by Ivanov et al. (2004) increased the number of type A observations to 17 for Antarctica, although 2 of these were observations at abyssal depths in the Weddell Sea, far beyond the shelf edge. The updated catalogue we present increases the number of positive DSW cascade observations to 27, and also includes 20 passive occurrences and 41 negative findings, all of them placed at or near the shelf break and covering almost the entire Antarctic continental margins (Fig. 1 and Table 1).

\section{Methods}

In this study we use bathymetry from the International Bathymetric Chart of the Southern Ocean (IBCSO) Version 1.0 (Arndt et al., 2013). The IBCSO provides a $500 \mathrm{~m}$ resolution digital bathymetric model of circum-Antarctic waters south of $60^{\circ}$ (Fig. 2), although the resolution of the gridded source data varies depending on the available sounding information. On the continental shelf and upper slope, the focus of this study, $28 \%$ of the IBCSO grid is constrained with high-resolution bathymetric data, acquired mainly by multibeam echo-sounders (Jakobsson et al., 2016). The rest of the grid is based on low-resolution interpolation between measurements (Arndt et al., 2013).

We digitised the shelf break manually using ArcGIS 10.4 at a spatial scale of 1:300,000. This was carried out with the guidance of bathymetric contours at $50 \mathrm{~m}$ intervals and slope-gradient maps. In areas permanently covered by ice, the shelf break was linearly interpolated between the two closest ice-free points. The coastline used in this study is from the SCAR Antarctic Digital Database.

For our analysis, the Antarctic continental shelf was divided into 10 different zones based on spatial and physiographic coherence (Fig. 2). The segmentation used here is broadly similar to other largescale subdivisions found in the literature (Paolo et al., 2015). For each zone, a series of statistics were calculated using ArcGIS and the R statistical package (Table 2 and Fig. 3a). The maximum, minimum and mean continental-shelf width were calculated by measuring the closest distance from the shelf break to the coastline at $1 \mathrm{~km}$ intervals along the shelf break, as undertaken previously by Harris and Macmillan-Lawler (2016). Our calculation neglects the presence of islands on the shelf smaller than $2 \mathrm{~km}^{2}$ and the cavities under ice shelves. For volume measurements (Table 2 and Supplementary Fig. 1), the IBCSO grid was first converted to a triangular irregular network (TIN) surface. The mean Antarctic continental-shelf depth $(460 \mathrm{~m})$ was then used as a reference polygon for the ArcGIS Polygon Volume tool. 
Polygons delineating the ice shelves were obtained from the SCAR Antarctic Digital Database, and those representing the polynyas were digitised from Nihashi and Ohshima (2015) (Fig. 1). The distance between the DSW downslope observations and the main ice shelves (5) and coastal polynyas (13) was calculated using the ArcGIS tool Cost Distance. This method allowed determination of the least costly path of a hypothetical dense-water particle sourced near the major ice shelves and polynyas to reach the observation points.

To assess the major factors influencing DSW cascades (Fig. 3b), all the hydrographic observation points were relocated to the closest shelf-break position. Where several observations of salinity, temperature and flux existed for the same DSW cascade event, only that closest to the shelf break was taken into account. The latitudes of observations reported as cross-slope temperature and salinity sections (Baines and Condie, 1998; Martinson and McKee, 2012) were obtained by referencing the profiles to the digitized shelf break.

\section{Results}

\subsection{Physiography of the Antarctic continental shelf}

Each of the 10 continental-shelf zones defined in this study shows a distinctly different morphometry (Fig. 3a, Table 2). The widest shelves are observed on the Ronne-Filchner and Ross Sea continental shelves, with a mean of $272 \pm 4 \mathrm{~km}$ and $238 \pm 3 \mathrm{~km}$, respectively. These shelf widths are more than double the mean for the whole Antarctic continental shelf $(114 \pm 1 \mathrm{~km})$, and only the Bellingshausen, Amundsen and East Antarctic Peninsula sectors are more than half as wide as the Ronne-Filchner and Ross Sea shelves. Correspondingly, the maximum shelf widths were also found in the Ronne-Filchner $(423 \mathrm{~km})$ and Ross Sea $(399 \mathrm{~km})$ sectors. The narrowest shelf is East Antarctica 1, from Riiser-Larsen Ice Shelf to Kemp Land, with a maximum shelf width of $87 \mathrm{~km}$ and a mean of $31 \pm 0.5 \mathrm{~km}$. The Ronne-Filchner and Ross Sea sectors also have quite similar continental-shelf areas, at $379,710 \mathrm{~km}^{2}$ and $384,060 \mathrm{~km}^{2}$, respectively. The differences between the Ronne-Filchner and Ross Sea continental shelves emerge when comparing their depths and physiography. On average, the Ross Sea is deeper (507 m) than the Ronne-Filchner sector of the Weddell Sea (471 m); 63\% of the Ross sector is under $460 \mathrm{~m}$, which is the mean depth for the entire Antarctic continental shelf, whereas for the RonneFilchner sector this ratio is only $41 \%$. At the shelf break the mean depth is $588 \mathrm{~m}$ for the Ross Sea shelf - the deepest of all 10 studied zones - and $492 \mathrm{~m}$ for the Ronne-Filchner segment. This difference is explained by numerous large bathymetric cross-shelf troughs that reach the shelf edge in the Ross Sea area in comparison to only three less extensive depressions observed in the RonneFilchner sector (Fig. 1, 2). Interestingly, the deep-water areas below $460 \mathrm{~m}$ are interconnected along the Ross Sea shelf but are separated by shallow ridges in the Ronne-Filchner area. However, the largest and deepest depression in the Ronne-Filchner sector, the Filchner Trough, shows a storage per $\mathrm{km}^{2}$ of $242 \mathrm{~km}^{3}$ between the seafloor and the $460 \mathrm{~m}$ contour (ice cavities excluded), whereas the storage per $\mathrm{km}^{2}$ of all the Ross Sea depressions together is $129 \mathrm{~km}^{3}$ (see Supplementary Fig. 1).

Only the Amundsen Sea shelf is deeper than the Ross Sea shelf. It has an average depth of $541 \mathrm{~m}$, with $70 \%$ of its area and $66 \%$ of its shelf break deeper than $460 \mathrm{~m}$. These values stand out as extremes in our analysis, far exceeding the Antarctic-wide averages of $48 \%$ and $29 \%$, respectively (Table 2a). The Bellingshausen Sea sector shows a similar range to the Amundsen Sea although it is notably shallower, with a mean water depth of $493 \mathrm{~m}$. Contrasting with the Amundsen Sea, the East Antarctica 1 sector has the shallowest mean depth $(331 \mathrm{~m})$, the minimum proportion of area deeper than $460 \mathrm{~m}$ $(12 \%)$ and the minimum proportion of shelf break below $460 \mathrm{~m}(8 \%)$. The Western Antarctic 
Peninsula area is the zone most comprehensively surveyed by multibeam echo-sounders (32\%) (Arndt et al., 2013) and displays both the second shallowest mean depth (388 $\mathrm{m}$ ) and the secondlowest proportion of shelf break below $460 \mathrm{~m}(13 \%)$.

Zone East Antarctica 3, from Queen Mary Land to Oates Land, is the longest (4,990 km) and largest $\left(484,235 \mathrm{~km}^{2}\right)$ segment we examined. Its mean shelf width is relatively narrow $(103 \pm 1 \mathrm{~km})$; it is only wider than the East Antarctica 1 and 2 sectors and that offshore of Marie Byrd Land. The East Antarctica 3 segment contains the largest volume deeper than $460 \mathrm{~m}$ water depth $\left(37,610 \mathrm{~km}^{3}\right)$, representing $21 \%$ of the total in Antarctica. This value is unsurprising given the large area covered by East Antarctica 3, but it should be noted that this zone is poorly covered (6\%) by high-resolution bathymetry (Arndt et al., 2013), so the position of the shelf break is less certain and the bathymetric grids likely contain artefacts.

\subsection{Distribution of DSW cascades}

The 88 hydrographic observations compiled are all located at or near the shelf break and cover all 10 zones under study (Fig. 1 and Table 2b). Confirmed DSW cascade observations (A) are 27 in total and are located in zones East Antarctica 2, East Antarctica 3, Ross, East Antarctic Peninsula and Ronne-Filchner. The 20 inferred (P) observations, all of them compiled by Baines and Condie (1998), are found in zones East Antarctica 1, 2, 3 and Ross. Negative (N) observations (41) are distributed mainly along the Pacific side of the continent, mostly between zones Marie Byrd Land and West Antarctic Peninsula, but also in East Antarctica 1 and Ronne-Filchner.

Observations of both active and passive DSW cascades coincide with the presence of ice shelves, the only exceptions being East Antarctica 1 and 3 (Fig. 3b and 4a). Four of the five main ice shelves in Antarctica - the Ross, Ronne-Filchner, Larsen and Amery - are associated with wide continental shelves (207-423 km), and all of them show active DSW cascades (Fig. 3 and Table 2a). Only the eastern side of the Filchner Trough, in the Ronne-Filchner zone, shows negative observations on the shelf edge. The Riiser-Larsen Ice Shelf (zone East Antarctica 1) is linked to a very narrow, in places apparently non-existent, continental shelf with no observed DSW flows. In contrast, East Antarctica 3 has the highest number (19 in total) of active and passive observations. These observations are located at the furthest mean distance from any of the main ice shelves (Table 2b), but are near productive coastal polynyas that, in some cases, extend out to the continental-shelf edge (Fig. 1 and Table $2 b$ ). The remaining set of active and passive observations are also located near polynyas (Fig. $3 \mathrm{~b}, 4 \mathrm{~b}$ and $5 \mathrm{c}, \mathrm{d})$. The most distant observations from polynyas are the ones located on the largest continental shelves, i.e. Ross and Ronne-Filchner. Only observations 8, 9 and 10 (Fig. 1 and Table 1), all of them passive, appear unrelated to either ice shelves or polynyas (Fig. 4a,b).

\section{Discussion}

\subsection{Controls on dense shelf-water cascades}

DSW overflows at the shelf edge, leading to down-slope cascades, have been reported from several rather different modern settings around the Antarctic continental margin. The presence of ice shelves and polynyas are generally considered to be the main factors influencing the occurrence of these dense flows, together with the generally large and deep Antarctic shelves that favour the accumulation and propagation of dense water from source areas to shelf edge (Baines and Condie, 1998; Ivanov et 
al., 2004; Killworth, 1983). Here we test this assertion by using the available observational data and we place it into its oceanographic context. It should be pointed out, however, that other regional factors like seasonal winds and strong tides are omitted in our broad-scale study although they can enhance, diminish or divert the cold bottom-currents, especially along wide continental shelves like those of the Weddell and Ross seas (Foldvik et al., 2004; Gordon et al., 2010, 2009; Padman et al., 2009).

The first active DSW cascade observations were reported in zones Ronne-Filchner, Ross, East Antarctica 2 and East Antarctic Peninsula (Table 1), all of them associated with large ice shelves and active polynyas (Fig. 4a,b) and adjacent to extensive continental shelves (Fig. 1 and 3), with only one exception (observation 11 in East Antarctica 2). These areas have long been considered as the only regions capable of generating sufficient negative buoyancy in local DSW for export to AABW (Foster and Carmack, 1976; Jacobs et al., 1970; Killworth, 1983). Their wide, deep and landward-sloping continental shelves favour the accumulation of cold and dense water between the shelf edge and the ice shelves grounding-line (Fahrbach et al., 1994; Ivanov et al., 2004) (Fig. 6). The numerous troughs spanning these shelves, roughly highlighted by the $460 \mathrm{~m}$ bathymetric contour (Fig. 1 and Supplementary Fig. 1), act as efficient drainage conduits for the transport of DSW to the shelf edge (Bergamasco et al., 2002; Lacarra et al., 2014). This observation is in agreement with the depth of the isotherm delineating the boundary of DSW reported in Ronne-Filchner (Darelius et al., 2014; Foldvik et al., 2004), Ross (Gordon et al., 2004) and East Antarctica 2 (Yabuki et al., 2006). In fact, the maximum DSW cascading fluxes calculated with the available current data from Antarctica are associated with the outlets of the largest depressions in Ronne-Filchner (i.e. Filchner Trough) and Ross (i.e. Drygalski Trough), with estimates of 1.6 $\pm 0.5 \mathrm{~Sv}$ (Foldvik et al., 2004) and 0.8 Sv (Gordon et al., 2009), respectively. These two settings also register the highest DSW outflow speeds with mean values of $0.45 \mathrm{~m} \mathrm{~s}^{-1}$ in Ronne-Filchner (Foldvik et al., 2004) and $0.6 \mathrm{~m} \mathrm{~s}^{-1}$ in Ross (R. Muench et al., 2009). The fact that active DSW cascades are observed only on the western side of the Filchner Trough outlet is due to the Coriolis force, which also explains the accumulation of dense-water cascades in the western Ross Sea.

The occurrence of DSW cascades discovered after the mid-1990s near the highly productive Mertz Polynya, in zone East Antarctica 3, broadened our understanding of potential source areas (Foster, 1995; Rintoul, 1998; Williams et al., 2010, 2008). The continental shelf in this area is relatively narrow, has limited DSW storage capacity, and is not close to any large ice shelf (Fig. 3). Over the last two decades new DSW cascades have been recorded in similar settings which have highly productive polynyas, such as zones East Antarctica 2 and 3, both important for the ventilation of the deep Indian and Pacific Ocean (Fukamachi et al., 2000; Kitade et al., 2014; Nakano and Suginohara, 2002; Ohshima et al., 2013; Williams et al., 2016; Yabuki et al., 2006). Today we observe that it is actually the presence of polynyas, not ice shelves per se, that is most strongly correlated with DSW cascades (active or passive) (Fig. 5b,d and Supplementary Fig. 2). Moreover, some of the observations near polynyas that were flagged as passive in Baines and Condie (1998) have now been confirmed to be active (see observations 16 and 17, 24 and 25 in Fig.1 and Table 1). The calculated fluxes of DSW export to the continental slope in these "polynya-only" zones are surprisingly high considering their limited storage capacity. Note, for instance, that the annual-averaged volume transport sourced from the Mertz Polynya (before the calving of 78 x $35 \mathrm{~km}$ of the Mertz Glacier tongue in 2010) was 0.1 to $0.5 \mathrm{~Sv}$ (Williams et al., 2008); in Vincennes Bay Polynya (zone East Antarctica 3) it was $0.16 \pm 0.25 \mathrm{~Sv}$; and in Cape Darnley Polynya, today the second most productive polynya in Antarctica after the Ross Ice Shelf Polynya (Fig. 1), it is $0.52 \pm 0.26 \mathrm{~Sv}$ (Ohshima et al., 
2013). More findings of active DSW production are anticipated from the still little studied regions of the East Antarctica margin.

\subsection{Waxing and waning of modern DSW cascades}

The aforementioned Mertz Glacier calving event in February 2010 affected the Mertz Polynya, causing a rapid weakening of DSW and AABW production (Kusahara et al., 2011; Lacarra et al., 2014; Menezes et al., 2017; Shadwick et al., 2013; Snow et al., 2018, 2016). This event highlights the uncertainty in defining polynya-based DSW regions (i.e. zones East Antarctica 2 and 3). As another example, observational data in Prydz Bay (Observation 12 in zone East Antarctica 2) recently demonstrated a progressive DSW waning in the ice shelf-polynya system. In this case, the weakening of DSW flux was due to increased freshwater input from greater melting of the Amery Ice Shelf (Williams et al., 2016).

The thinning of ice shelves has been attributed mainly to basal melt by relatively warm and saline ocean waters entering sub-ice shelf cavities. The most rapid thinning, grounding-line retreat, and acceleration of glacier flow speeds has been observed in the Amundsen Sea (Paolo et al., 2015; Rignot et al., 2013). Here, similarly to the Bellingshausen Sea, wind forcing, upwelling and vertical mixing drive warm (over $1^{\circ} \mathrm{C}$ ) Circumpolar Deep Water (CDW) onto the continental shelf (Thoma et al., 2008), where it flows through the numerous bathymetric depressions until it reaches the base of the ice shelves (e.g. Walker et al., 2007) (Fig. 6f,g and Supplementary Fig. 1). This inflow process is favoured by the close proximity of CDW flows to the continental margin in the south east Pacific sector of Antarctica (Pritchard et al., 2012; Walker et al., 2013, 2007). These incursions are most pronounced in the deep shelf regions (541 m on average) observed on the Amundsen Sea continental shelf (Fig. 3a and Table 2a). Here DSW formed in the Amundsen Polynya, the second largest polynya in West Antarctica in terms of ice production (Fig. 1), is probably inhibited by the geostrophically driven outflow generated from basal melt under the floating margins of Pine Island and Thwaites glaciers, as suggested by $(\mathrm{N})$ observations 44 to 48 (Table 1). A similar explanation can be offered for the $(\mathrm{N})$ observations in the Bellingshausen Sea, the zone with the second highest percentage of area and shelf edge deeper than $460 \mathrm{~m}$ after the Amundsen Sea sector (Fig. 3a and Table 2a). In Western Antarctic Peninsula and Marie Byrd Land, the incursion of relatively warm ocean waters (Fig. 6e,h) and the lack of polynyas and ice shelves also appear to prevent the present-day formation of DSW (Fig. 4a,b), whereas in zone East Antarctica 1 the absence of DSW is probably related to the lack of coastal polynyas and the narrowness of its continental shelf (Fig. 3, 4c and 6a). Observations 8 to 10 in East Antarctica 1 are documented as passive in Baines and Condie (1998) although the analysis of broad-scale controlling factors we present here (Fig. 3b and Fig. 5b) suggests that these are probably inactive under current conditions.

Although ice shelves in East Antarctica experience relatively low rates of basal melt (Rignot et al., 2013), one clear exception has been observed recently on the East Antarctica 3 shelf adjacent to Dalton Polynya (Rintoul et al., 2016; Silvano et al., 2017). Modified CDW reaches the bases of the nearby Totten and Moscow University ice shelves, probably by means of uncharted troughs, resulting in basal melt rates comparable to those in the Amundsen and Bellingshausen zones. The meltwater generated likely inhibits the formation of DSW, as indicated by the relatively low rates of sea-ice production at Dalton Polynya (Silvano et al., 2017). Hence, Observation 19 in Table 1 registered as passive (P) in March 1996 is now known to be negative $(\mathrm{N})$. Whether or not this reflects a change in 
ocean-ice shelf interaction in this area is unclear but it does suggest that East Antarctica could be more exposed to warm CDW incursions than was previously thought.

The dual role of deep shelf-crossing troughs as conduits for DSW export and CDW inflows is critical to our understanding of ice-sheet behaviour and AABW formation. It is hypothesized that the Filchner Trough, today an efficient route for DSW flowing out from the eastern Ronne-Filchner shelf (Fig. $6 \mathrm{j}$ ), is likely to channelize the cyclonic warm CDW underneath the Filchner-Ronne Ice Shelf during the second half of the twenty-first century (Hellmer et al., 2012). This scenario, based on a regional ice-ocean simulation model, would likely lead to severe mass-balance deficit across the second largest Antarctic ice shelf and a substantial reduction in the export of DSW cascades and AABW formation in the whole Ronne-Filchner zone in the Weddell Sea.Hydrographic lines from the Southern Ocean (Purkey and Johnson, 2010), specifically in the Indian sector (Menezes et al., 2017) and Weddell Sea (Fahrbach et al., 2011), reveal the progressive freshening and warming of the AABW observed over the last decade, which might be related to the weakening of DSW formation.

Sediment records on the Amundsen Sea shelf provide geochemical evidence of variability in CDW inflows during the Holocene (Hillenbrand et al., 2017). By contrast, the changing nature of seafloor bedforms, observed in sediment cores from the shelf of East Antarctica 2, suggest variability in DSW outflows during the last 10,000 years or so (Harris, 2000). It has also been suggested that some of the drainage morphologies, especially gullies and shelf-edge canyons, observed on the upper slope of the Antarctic continental margin could have been shaped by the action of modern and/or past DSW cascades (Amblas et al., 2017; Dowdeswell et al., 2006; Gales et al., 2014). Like deep troughs on the continental shelf, submarine shelf-edge canyons and gullies allow for bidirectional transport on the continental slope by either channelling seaward DSW fluxes or delivering warm CDW onto shelves, the latter often triggered by eddies (Allen and Durrieu de Madron, 2009; Kämpf, 2005; Martinson and McKee, 2012; Stewart and Thompson, 2015).

\subsection{Cascading dense water during Quaternary full-glacial periods}

The absence of DSW cascades in East Antarctica 1, where the modern grounding-lines of the ice shelves lie unusually near the shelf break (Fig. 1), prompts the question of how AABW was produced during Quaternary full-glacial periods (Smith et al., 2010), when most of the grounded ice in Antarctica advanced to the continental-shelf edge (Bentley et al., 2014). In this extended position, relatively warm water was therefore in close proximity to the ice sheet, implying melting at the base of the ice shelves at rapid enough rates to negate the salt released by surface freezing in the polynyas (Fahrbach et al., 1994). Clearly the decline of continental shelf areas free of grounded ice during glacial periods (e.g. Bentley et al., 2014) also prevented the accumulation of large volumes of cold and dense water in source areas on the shelf.

The lack of controlling factors (i.e. large ice shelves, coastal polynyas and large cross-shelf depressions) currently identified in zones Ronne-Filchner, Ross, East Antarctic Peninsula and East Antarctica 2 and 3 requires an alternative explanation. A possible candidate for dense-water production during full-glacials may be open-ocean polynyas produced when deep-ocean convection injects relatively warm water into the surface layer, inhibiting sea-ice formation (Gordon et al., 2007). This process is rare in the present-day Southern Ocean, although a prominent example - the Weddell Polynya $\left(3 \times 10^{5} \mathrm{~km}^{2}\right)$ - was observed during the austral winters of 1974 to 1976 seaward of zone East Antarctica 1 (Gordon et al., 2007; Weijer et al., 2017). Another possibility is that the Antarctic Ice Sheet only partially covered the continental shelf in some areas that are today dominated by ice 
shelves, such that AABW production was similar to that observed today. This has been suggested by some authors for parts of the Weddell Sea (Hillenbrand et al., 2014), the Amundsen Sea (Klages et al., 2017) and Prydz Bay (Domack et al., 1998), which may therefore have had full-glacial AABW production processes similar to those operating today. This last hypothesis is controversial and does not account for AABW generated in polynya-only settings despite these standing out as important sources of cascading DSW today.

\section{Conclusions}

This pan-Antarctic and nearly 50 years long compendium of hydrographic observations has allowed the analysis of the main broad-scale factors, both cryospheric and physiographic, that explain the distribution of DSW cascades around Antarctica. The relatively recent discovery of DSW cascades on the narrow continental shelves of East Antarctica highlighted the role of coastal polynyas in the formation of these dense-water flows. In our analysis a clear relationship between the distribution of polynyas and DSW cascades around Antarctica is observed, whereas cascades appear to be less closely related to the presence of large ice shelves or vast continental shelves, both previously considered to be necessary for the formation of large volumes of DSW. Even though the current dataset indicates that the maximum fluxes of DSW cascades are found at the outlets of RonneFilchner and Ross embayment zones, we note the surprisingly high fluxes of DSW export to the continental slope observed in "polynya-only" zones, especially considering their limited storage capacity.

The few decades of available DSW cascading records reviewed in this study are enough to observe a reduction of DSW export in some areas. This weakening of DSW formation in the Antarctic continental shelves may partly explain the observed progressive AABW weakening, warming and volume reduction. This highlights the variability of these complex ice-ocean systems and their vulnerability in the face of rapid climate change. Major causes of the weakening of DSW fluxes are considered to be: a) the collapse of glacier ice tongues that lead to the dramatic waning of polynyas (e.g. Mertz Polynya); and b) the incursion of warm CDW into sub-ice shelf cavities causing the increased basal melt of ice shelves and a relative rise in freshwater inputs that reduce (e.g. Prydz Bay) or even halt (e.g. Amundsen Bay) the downslope export of DSW. We have demonstrated how this last phenomenon is largely determined by the physiography of continental shelves; essentially the mean shelf depth, the depth of the shelf edge and the presence of cross-shelf troughs that either facilitate the export of DSW or the channelization of CDW inflows. The role played by drainage morphologies on the continental shelf (cross-shelf troughs) and slope (submarine canyons and gullies) in the propagation and concentration of DSW fluxes and their influence on the formation of AABW is currently under study. The mechanisms for DSW and AABW formation during Quaternary fullglacial periods, when most of the Antarctic ice-sheet margin was grounded at or near the continentalshelf edge (Bentley et al., 2014) and therefore more exposed to CDW, remains unclear.

\section{Acknowledgements}

This project has received funding from the European Union's Horizon 2020 research and innovation programme under Marie Sklodowska-Curie grant agreement No. 658358. We thank Hugo Tavares (Sainsbury Laboratory, University of Cambridge) for his valuable help with the analysis of the data in R software, and Thomas P. Gerber (Statoil - Research and Technology) and Keith W. Nicholls 
(British Antarctic Survey) for providing very useful comments on an earlier version of the manuscript. We also thank Gerhard Kuhn (AWI) and an anonymous reviewer for constructive reviews that helped shape and improve the manuscript.

\section{Figure Captions}

Table 1. Compendium of water column observations, including observation number $(N)$, location, type of observation ( $T$; A: active, P: passive, N: Nil), date of observation, method of acquisition and reference. Different publications that refer to the same station site are grouped under the same observation number while stations separated by less than $1^{\circ}$ of arc are coded with the same number but different letter. B\&C (following Baines and Condie, 1998). ADCP is Acoustic Doppler Current Profiler; LADCP is Lowered ADCP; CTD is Conductivity Temperature Depth; XCTD is expandable CTD; XBT is Expandable Bathy Thermograph; SACM is Smart Acoustic Current Meter (suspended through the ice); CTD-ES is CTD installed on elephant seals. Moorings include current meters, and temperature and salinity sensors (Gordon et al., 2004; R. D. Muench et al., 2009 also include sediment traps). For details about the instrumentation see the original references.

Table 2. a) Summary of physiographic statistics for the Antarctic continental shelf listed by zones (Fig. 2), all zones (excluding the shelves surrounding the Bransfield Strait, South Shetland Islands and South Orkney Islands) and as a global average for the whole Antarctic continental shelf (ANT). b) Number and type of DSW observations for each of the zones, as well as their mean distance to the main ice shelves and coastal polynyas. Brown and green colours show minimum and maximum values for each parameter. Volume under $460 \mathrm{~m}$ refers to the total volume between the seafloor and the $460 \mathrm{~m}$ bathymetric contour. See Fig. 3 for the graphical representation of these data.

Figure 1. Location of water column observations showing the presence or absence of dense shelfwater downslope flows around Antarctica (see observation details in Table 1). The coastline and ice shelf areas are derived from the SCAR Antarctic Digital Database. The $460 \mathrm{~m}$ contour and the continental shelf break are based on IBCSO v. 1.0 (Arndt et al., 2013). The major coastal polynyas and values of mean annual sea ice production are taken from Nihashi and Ohshima (2015). The size of the grey circles is proportional to the polynyas sea ice production. IS is ice shelf; $\mathrm{P}$ is polynya.

Figure 2. Bathymetric map of the Southern Ocean (IBCSO v. 1.0, Arndt et al., 2013). Solid white lines show the borders between the segments used for the morphometric analysis of the Antarctic continental shelf. Note that the shelves surrounding the Bransfield Strait, South Shetland Islands and South Orkney Islands are not considered in the analysis. Red and yellow lines mark the continental shelf break above (red) and below (yellow) $460 \mathrm{~m}$, which is the mean depth of the Antarctic continental shelf.

Figure 3. Synthetic graphs showing: a) the main morphometric values that describe each of the Antarctic continental shelf zones identified in Fig. 2. Vertical dotted lines mark the mean values for the whole Antarctic shelves; b) the distance from each of the DSW cascade observations (Table 1) to the main polynyas, ice shelves and the coastline (see Supplementary Fig. 2 for details on the calculation method). Green and grey vertical dotted lines show, for each of the shelf zones, the mean distance from polynyas and ice shelves to each of the $1 \mathrm{~km}$-spaced measures at the shelf break (see 
"Material and methods" for details). EA1 is East Antarctica 1; EA2 is East Antarctica 2; EA3 is East Antarctica 3; MBL is Marie Byrd Land; Amu is Amundsen; Bel is Bellingshausen; WAP is West Antarctic Peninsula; EAP is East Antarctic Peninsula; R/F is Ronne-Filchner.

Figure 4. Box-and-whisker plots showing the distribution of the distance to a) major polynyas and b) larger ice shelves for all the DSW cascade observations for each of the Antarctic shelf zones (see mean distance values at Table $2 \mathrm{~b}$ ). Whiskers have a range of $1.5 \mathrm{IQR}$. Outliers are plotted as individual points.

Figure 5. a,b) Box-and-whisker plots showing the distribution of active, passive and nil DSW cascade observations for the distance to large ice shelves (a) and to major polynyas (b). Whiskers have a range of 1.5 IQR and outliers are plotted as individual points. c,d) Frequency distribution of the DSW cascade observations for the distance to larger ice shelves (c) and to major polynyas (d) at $250 \mathrm{~km}$ intervals. The correlation between the distribution of DSW cascade observations (active or passive) and the presence of polynyas is relatively stronger than for ice shelves (Fig. 5b,d).

Figure 6. Sketch of the modern set up of DSW cascades (in blue) and CDW inflows (in purple) in the different Antarctic sectors considered. The distribution of DSW and CDW is based on the reviewed observations (Fig. 1 and Table 1) and on the estimated average sea-floor potential temperatures map published in Pritchard et al. (2012), respectively. The topographic and bathymetric profiles have been calculated from the IBCSO v1.0 grid (Arndt et al., 2013) and the subglacial bed elevation from the Bedmap2 grid (Fretwell et al., 2013). The profiles follow main ice-sheet flow directions, cross-shelf trough axes and slope drainage morphologies, whenever present. The sub-ice shelf cavity delineations are approximate.

Supplementary Figure 1. Areas below the $460 \mathrm{~m}$ depth contour (mean Antarctic continental shelf depth) showing the main troughs $\left(>100 \mathrm{~km}^{2}\right)$ in the Antarctic continental shelves. The colour scale represents the total volume between the seafloor and the $-460 \mathrm{~m}$ contour for each of the troughs (see the volume values for zones in Table 2). Note that connected troughs are considered a single polygon in terms of volume calculations. Grey circles illustrate the mean water storage per area for the main troughs or cluster of connected troughs. Location of water column observations (Table 1) are included for reference.

Supplementary Figure 2. Matrix plot relating the water column observations (Table 1) to the distance to major coastal polynyas (a), distance to larger ice shelves (e) and continental shelf width (i), which are considered to be the main factors controlling the distribution of DSW cascades. The distance between the DSW downslope observations and the main ice shelves is calculated from the ice front. The Pearson correlation coefficient ( $\mathrm{r}$ ) is included for each pair of variables. A is Active; $\mathrm{P}$ is Passive; $\mathrm{N}$ is Nil.

\section{References}

Allen, S.E., Durrieu de Madron, X., 2009. A review of the role of submarine canyons in deep-ocean exchange with the shelf. Ocean Sci. Discuss. 6, 1369-1406. https://doi.org/10.5194/osd-6-1369-2009 
Amblas, D., Ceramicola, S., Gerber, T.P., Canals, M., Chiocci, F.L., Dowdeswell, J.A., Harris, P.T., Huvenne, V.A.I., Lai, S.Y.J., Lastras, G., Lo Iacono, C., Micallef, A., Mountjoy, J.J., Paull, C.K., Puig, P., Sanchez-Vidal, A., 2017. Submarine Canyons and Gullies, in: Micallef, A., Krastel, S., Savini, A. (Eds.), Submarine Geomorphology. Springer International Publishing, Cham, pp. 251-272. https://doi.org/10.1007/978-3-319-57852-1_14

Antipov, N.N., Batrak, K.V., Dukhova, L.A., Kuznetsov, V.L., Maslennikov, V.V., 2009. Hydrologicalhydrochemical studies performed onboard R/V Akademik Fedorov during the 53th Russian Antarctic Expedition. Oceanology 49, 155-158. https://doi.org/10.1134/S0001437009010172

Arndt, J.E., Schenke, H.W., Jakobsson, M., Nitsche, F.O., Buys, G., Goleby, B., Rebesco, M., Bohoyo, F., Hong, J., Black, J., Greku, R., Udintsev, G., Barrios, F., 2013. The International Bathymetric Chart of the Southern Ocean ( IBCSO ) Version 1.0 - A new bathymetric compilation covering circumAntarctic waters 40, 3111-3117. https://doi.org/10.1002/grl.50413

Baines, P.G., Condie, S., 1998. Observations and modelling of Antarctic downslope flows: a review. Ocean. ice Atmos. Interact. Antarct. Cont. margin 75, 29-49. https://doi.org/10.1029/AR075p0029

Bentley, M.J., O'Cofaigh, C., Anderson, J.B., Conway, H., Davies, B., Graham, A.G.C., Hillenbrand, C.D., Hodgson, D.A., Jamieson, S.S.R., Larter, R.D., Mackintosh, A., Smith, J.A., Verleyen, E., Ackert, R.P., Bart, P.J., Berg, S., Brunstein, D., Canals, M., Colhoun, E.A., Crosta, X., Dickens, W.A., Domack, E., Dowdeswell, J.A., Dunbar, R., Ehrmann, W., Evans, J., Favier, V., Fink, D., Fogwill, C.J., Glasser, N.F., Gohl, K., Golledge, N.R., Goodwin, I., Gore, D.B., Greenwood, S.L., Hall, B.L., Hall, K., Hedding, D.W., Hein, A.S., Hocking, E.P., Jakobsson, M., Johnson, J.S., Jomelli, V., Jones, R.S., Klages, J.P., Kristoffersen, Y., Kuhn, G., Leventer, A., Licht, K., Lilly, K., Lindow, J., Livingstone, S.J., Massé, G., McGlone, M.S., McKay, R.M., Melles, M., Miura, H., Mulvaney, R., Nel, W., Nitsche, F.O., O’Brien, P.E., Post, A.L., Roberts, S.J., Saunders, K.M., Selkirk, P.M., Simms, A.R., Spiegel, C., Stolldorf, T.D., Sugden, D.E., van der Putten, N., van Ommen, T., Verfaillie, D., Vyverman, W., Wagner, B., White, D.A., Witus, A.E., Zwartz, D., 2014. A community-based geological reconstruction of Antarctic Ice Sheet deglaciation since the Last Glacial Maximum. Quat. Sci. Rev. 100, 1-9. https://doi.org/10.1016/j.quascirev.2014.06.025

Bergamasco, A., Defendi, V., Zambianchi, E., Spezie, G., 2002. Evidence of dense water overflow on the Ross Sea shelf-break. Antarct. Sci. 14, 271-277. https://doi.org/10.1017/S0954102002000068

Budillon, G., Gremes Cordero, S., Salusti, E., 2002. On the dense water spreading off the Ross Sea shelf (Southern Ocean). J. Mar. Syst. 35, 207-227. https://doi.org/10.1016/S0924-7963(02)00082-9

Carmack, E.C., Foster, T.D., 1975. On the flow of water out of the Weddell Sea. Deep Sea Res. Oceanogr. Abstr. 22, 711-724. https://doi.org/10.1016/0011-7471(75)90077-7

Carmack, E.C., Killworth, P.D., 1978. Formation and interleaving of abyssal water masses off Wilkes Land, Antarctica. Deep Sea Res. 25, 357-369.

Chavanne, C.P., Heywood, K.J., Nicholls, K.W., Fer, I., 2010. Observations of the Antarctic Slope undercurrent in the Southeastern Weddell Sea. Geophys. Res. Lett. 37, 3-7.

https://doi.org/10.1029/2010GL043603

Darelius, E., Strand, K.O., Østerhus, S., Gammelsrød, T., Årthun, M., Fer, I., 2014. On the Seasonal Signal of the Filchner Overflow, Weddell Sea, Antarctica. J. Phys. Oceanogr. 44, 1230-1243. https://doi.org/10.1175/JPO-D-13-0180.1

Domack, E., O’Brien, P., Harris, P., Taylor, F., Quilty, P.G., Santis, L. De, Raker, B., 1998. Late Quaternary sediment facies in Prydz Bay, East Antarctica and their relationship to glacial advance onto the continental shelf. Antarct. Sci. 10, 236-246. https://doi.org/10.1017/S0954102098000339

Dowdeswell, J.A., Evans, J., O'Cofaigh, C., Anderson, J.B., 2006. Morphology and sedimentary processes on the continental slope off Pine Island Bay, Amundsen Sea, West Antarctica. Bull. Geol. Soc. Am. 118, 606-619. https://doi.org/10.1130/B25791.1 
Fahrbach, E., Hoppema, M., Rohardt, G., Boebel, O., Klatt, O., Wisotzki, A., 2011. Warming of deep and abyssal water masses along the Greenwich meridian on decadal time scales: The Weddell gyre as a heat buffer. Deep. Res. Part II Top. Stud. Oceanogr. 58, 2509-2523.

https://doi.org/10.1016/j.dsr2.2011.06.007

Fahrbach, E., Peterson, R.G., Rohardt, G., Schlosser, P., Bayer, R., 1994. Suppression of bottom water formation in the southeastern Weddell sea. Deep. Res. Part I 41, 389-411. https://doi.org/10.1016/09670637(94)90010-8

Fahrbach, E., Rohardt, G., Scheele, N., Schröder, M., Strass, V., Wisotzki, A., 1995. Formation and discharge of deep and bottom water in the northwestern Weddell Sea. J. Mar. Res. 53, 515-538. https://doi.org/10.1357/0022240953213089

Foldvik, A., Gammelsrød, T., Øesterhus, S., Fahrbach, E., Rohart, G., Schröder, M., Nicholls, K.W., Padman, L., Woodgate, R.A., 2004. Ice shelf water overflow and bottom water formation in the southern Weddell Sea. J. Geophys. Res. 109, doi:10.1029/2003JC002008. https://doi.org/10.1029/2003JC002008

Foldvik, A., Gammelsrød, T., Tørresen, T., 1985. Circulation and water masses on the southern Weddell Sea shelf. Oceanol. Antarct. Cont. Shelf 43, 5-20. https://doi.org/10.1029/AR043p0005

Foldvik, A., Gammelsrød, T., Tørresen, T., 1985b. Physical oceanography studies in the Weddell Sea during the Norwegian Antarctic Research Expedition 1978/79. Polar Res. 3, 195-207. https://doi.org/10.1111/j.1751-8369.1985.tb00507.x

Foldvik, A., Gammelsrød, T., Tørresen, T., 1985a. Hydrographic observations from the Weddell Sea during the Norwegian Antarctic Research Expedition 1976/77. Polar Res. 3, 177-193. https://doi.org/10.3402/polar.v3i2.6951

Foster, T.D., 1995. Abyssal water mass formation off the eastern Wilkes land cost of Antarctica. Deep. Res. Part I 42, 501-522. https://doi.org/10.1016/0967-0637(95)00002-N

Foster, T.D., Carmack, E.C., 1976. Frontal zone mixing and Antarctic Bottom water formation in the southern Weddell Sea. Deep. Res. Oceanogr. Abstr. 23, 301-317. https://doi.org/10.1016/0011-7471(76)90872$\mathrm{X}$

Foster, T.D., Foldvik, A., Middleton, J.H., 1987. Mixing and bottom water formation in the shelf break region of the southern Weddell Sea. Deep Sea Res. Part A, Oceanogr. Res. Pap. 34, 1771-1794. https://doi.org/10.1016/0198-0149(87)90053-7

Fretwell, P., Pritchard, H.D., Vaughan, D.G., Bamber, J.L., Barrand, N.E., Bell, R., Bianchi, C., Bingham, R.G., Blankenship, D.D., Casassa, G., Catania, G., Callens, D., Conway, H., Cook, A.J., Corr, H.F.J., Damaske, D., Damm, V., Ferraccioli, F., Forsberg, R., Fujita, S., Gim, Y., Gogineni, P., Griggs, J.A., Hindmarsh, R.C.A., Holmlund, P., Holt, J.W., Jacobel, R.W., Jenkins, A., Jokat, W., Jordan, T., King, E.C., Kohler, J., Krabill, W., Riger-Kusk, M., Langley, K.A., Leitchenkov, G., Leuschen, C., Luyendyk, B.P., Matsuoka, K., Mouginot, J., Nitsche, F.O., Nogi, Y., Nost, O.A., Popov, S. V., Rignot, E., Rippin, D.M., Rivera, A., Roberts, J., Ross, N., Siegert, M.J., Smith, A.M., Steinhage, D., Studinger, M., Sun, B., Tinto, B.K., Welch, B.C., Wilson, D., Young, D.A., Xiangbin, C., Zirizzotti, A., 2013. Bedmap2: Improved ice bed, surface and thickness datasets for Antarctica. Cryosphere 7, 375-393. https://doi.org/10.5194/tc-7-375-2013

Fukamachi, Y., Wakatsuchi, M., Taira, K., Kitagawa, S., Ushio, S., Takahashi, A., Oikawa, K., Furukawa, T., Yoritaka, H., Fukuchi, M., Yamanouchi, T., 2000. Seasonal variability of bottom water properties off Adlie Land, Antarctica Shuki Hiroyuki 3 and Takashi Yamanouchi average current speed at the lower current is larger by $5.7 \mathrm{~cm} \mathrm{~s}-\bullet$ and temperature is lower by 105, 6531-6540.

Gales, J.A., Leat, P.T., Larter, R.D., Kuhn, G., Hillenbrand, C.D., Graham, A.G.C., Mitchell, N.C., Tate, A.J., Buys, G.B., Jokat, W., 2014. Large-scale submarine landslides, channel and gully systems on the southern Weddell Sea margin, Antarctica. Mar. Geol. 348, 73-87.

https://doi.org/10.1016/j.margeo.2013.12.002 
Gordon, A.L., 1993. Weddell Sea exploration from ice station. Eos, Trans. Am. Geophys. Union 74, 121-126. https://doi.org/10.1029/93EO00260

Gordon, A.L., 1982. Weddell deep water: Source and variability. Antarct. J. 40, 199-217.

Gordon, A.L., 1978. Deep Antarctic Convection West of Maud Rise. J. Phys. Oceanogr. https://doi.org/10.1175/1520-0485(1978)008

Gordon, A.L., 1975. An Antarctic oceanographic section along $170^{\circ}$ E. Deep Sea Res. 22, 357-377.

Gordon, A.L., Huber, B., McKee, D., Visbeck, M., 2010. A seasonal cycle in the export of bottom water from the Weddell Sea. Nat. Geosci. 3, 551-556. https://doi.org/10.1038/ngeo916

Gordon, A.L., Huber, B.A., Busecke, J., 2015. Bottom water export from the western Ross Sea, 2007 through 2010. Geophys. Res. Lett. 42, 5387-5394. https://doi.org/10.1002/2015GL064457

Gordon, A.L., Orsi, A.H., Muench, R., Huber, B.A., Zambianchi, E., Visbeck, M., 2009. Western Ross Sea continental slope gravity currents. Deep Sea Res. Part II Top. Stud. Oceanogr. 56, 796-817. https://doi.org/10.1016/j.dsr2.2008.10.037

Gordon, A.L., Visbeck, M., Comiso, J.C., 2007. A possible link between the Weddell Polynya and the southern annular mode. J. Clim. 20, 2558-2571. https://doi.org/10.1175/JCLI4046.1

Gordon, A.L., Zambianchi, E., Orsi, A., Visbeck, M., Giulivi, C.F., Whitworth, T., Spezie, G., 2004. Energetic plumes over the western Ross Sea continental slope. Geophys. Res. Lett. 31, 5-8. https://doi.org/10.1029/2004GL020785

Harris, P.T., 2000. Ripple cross-laminated sediments on the East Antarctic Shelf: Evidence for episodic bottom water production during the Holocene? Mar. Geol. 170, 317-330. https://doi.org/10.1016/S0025-3227(00)00096-7

Harris, P.T., Macmillan-Lawler, M., 2016. Global Overview of Continental Shelf Geomorphology Based on the SRTM30_PLUS 30-Arc Second Database. Springer International Publishing, pp. 169-190. https://doi.org/10.1007/978-3-319-25121-9_7

Hellmer, H.H., Jacobs, S.S., Jenkins, A., 1998. Oceanic erosion of a floating Antarctic glacier in the Amundsen Sea. Antarct. Res. Ser. 75, 83-99.

Hellmer, H.H., Kauker, F., Timmermann, R., Determann, J., Rae, J., 2012. Twenty-first-century warming of a large Antarctic ice-shelf cavity by a redirected coastal current. Nature 485, 225-228. https://doi.org/10.1038/nature11064

Heywood, K.J., Locarnini, R.A., Frew, R.D., Dennis, P.F., King, B.A., 1998. Transport and Water Masses of the Antarctic Slope Front System in the Eastern Weddell Sea 75, 203-214.

Hillenbrand, C.-D., Smith, J.A., Hodell, D.A., Greaves, M., Poole, C.R., Kender, S., Williams, M., Andersen, T.J., Jernas, P.E., Elderfield, H., Klages, J.P., Roberts, S.J., Gohl, K., Larter, R.D., Kuhn, G., 2017. West Antarctic Ice Sheet retreat driven by Holocene warm water incursions. Nature 547, 43-48. https://doi.org/10.1038/nature22995

Hillenbrand, C.D., Bentley, M.J., Stolldorf, T.D., Hein, A.S., Kuhn, G., Graham, A.G.C., Fogwill, C.J., Kristoffersen, Y., Smith, J.A., Anderson, J.B., Larter, R.D., Melles, M., Hodgson, D.A., Mulvaney, R., Sugden, D.E., 2014. Reconstruction of changes in the Weddell Sea sector of the Antarctic Ice Sheet since the Last Glacial Maximum. Quat. Sci. Rev. 100, 111-136. https://doi.org/10.1016/j.quascirev.2013.07.020

Hishida, M., 1975. On the relations between Antarctic Deep Water and oceanographic structure off LiitzowHolm Bay. Rep. Hydro. Res. 10, 51-74.

Hofmann, E.E., Klinck, J.M., 1998. Hydrography and circulation of the Antarctic continental shelf: $150^{\circ} \mathrm{E}$ eastward to the Greenwich meridian. Sea, Glob. Coast. Ocean. Reg. Stud. Synth. 11. 
Hofmann, E.E., Lipphardt, B.L., Smith, D.A., 1993. Palmer LTER: Hydrography in the LTER region. Antarct. J. U.S. 28, 209-211.

Huhn, O., Hellmer, H.H., Rhein, M., Rodehacke, C., Roether, W., Schodlok, M.P., Schröder, M., 2008. Evidence of deep- and bottom-water formation in the western Weddell Sea. Deep. Res. Part II Top. Stud. Oceanogr. 55, 1098-1116. https://doi.org/10.1016/j.dsr2.2007.12.015

Ivanov, V. V., Shapiro, G.I., Huthnance, J.M., Aleynik, D.L., Golovin, P.N., 2004. Cascades of dense water around the world ocean, Progress in Oceanography. https://doi.org/10.1016/j.pocean.2003.12.002

Jacobs, S.S., 2004. Bottom water production and its links with the thermohaline circulation. Antarct. Sci. 16, 427-437. https://doi.org/10.1017/S095410200400224X

Jacobs, S.S., 1991. On the nature and significance of the Antarctic Slope Front. Mar. Chem. 35, 9-24. https://doi.org/10.1016/S0304-4203(09)90005-6

Jacobs, S.S., Amos, A.F., Bruchhausen, P.M., 1970. Ross sea oceanography and antarctic bottom water formation. Deep Sea Res. Oceanogr. Abstr. 17, 935-962. https://doi.org/10.1016/0011-7471(70)90046$\mathrm{X}$

Jacobs, S.S., Fairbanks, R.G., Horibe, Y., 1985. Origin and evolution of water masses near the Antarctic continental margin: evidence from $\mathrm{H} 218 \mathrm{O} / \mathrm{H} 216 \mathrm{O}$ ratios in seawater. Oceanogr. Antarct. Cont. Shelf 43, 59-85. https://doi.org/10.1029/AR043

Jacobs, S.S., Georgi, D.T., 1977. Observations in the southwest Indian/Antarctic ocean, in A Voyage of Discovery. Suppl. to Deep. Res 24, 43-89.

Jacobs, S.S., Haines, W.E., Observatory, L.-D.G., Project, R.I.S., 1982. Oceanographic Data in the Ross Sea and Along George V Coast, 1976-1979. Lamont-Doherty Geological Observatory of Columbia University.

Jacobs, S.S., Hellmer, H., Schlosser, P., Smethie, W., 1994. An oceanographic expedition to the Amundsen and Bellingshausen Seas. Antarct. J. U.S. 29, 109-111.

Jakobsson, M., Gyllencreutz, R., Mayer, L.A., Dowdeswell, J.A., Canals, M., Todd, B.J., Dowdeswell, E.K., Hogan, K.A., Larter, R.D., 2016. Mapping submarine glacial landforms using acoustic methods. Geol. Soc. London, Mem. 46, 17-40. https://doi.org/10.1144/M46.182

Jensen, M.F., Fer, I., Darelius, E., 2013. Low frequency variability on the continental slope of the southern Weddell Sea. J. Geophys. Res. Ocean. 118, 4256-4272. https://doi.org/10.1002/jgrc.20309

Kämpf, J., 2005. Cascading-driven upwelling in submarine canyons at high latitudes. J. Geophys. Res. C Ocean. 110, 1-10. https://doi.org/10.1029/2004JC002554

Killworth, P.D., 1983. Deep convection in the world ocean. Rev. Geophys. Sp. Phys. 21, 1-26.

Kitade, Y., Shimada, K., Tamura, T., Williams, G.D., Aoki, S., Fukamachi, Y., Roquet, F., Hindell, M., Ushio, S., Ohshima, K.I., 2014. Antarctic bottom water production from the Vincennes Bay Polynya, East Antarctica. Geophys. Res. Lett. 41, 3528-3534. https://doi.org/10.1002/2014GL059971

Kusahara, K., Hasumi, H., Williams, G.D., 2011. Impact of the Mertz Glacier Tongue calving on dense water formation and export. Nat. Commun. 2, 159. https://doi.org/10.1038/ncomms1156

Lacarra, M., Houssais, M.-N., Herbaut, C., Sultan, E., Beauverger, M., 2014. Dense shelf water production in the Adélie Depression, East Antarctica, 2004-2012: Impact of the Mertz Glacier calving. J. Geophys. Res. Ocean. 119, 5203-5220. https://doi.org/10.1002/jgrc.20224

Livingstone, S.J., Ó Cofaigh, C., Stokes, C.R., Hillenbrand, C.D., Vieli, A., Jamieson, S.S.R., 2012. Antarctic palaeo-ice streams. Earth-Science Rev. 111, 90-128. https://doi.org/10.1016/j.earscirev.2011.10.003

Martinson, D.G., McKee, D.C., 2012. Transport of warm upper circumpolar deep water onto the Western Antarctic Peninsula Continental Shelf. Ocean Sci. 8, 433-442. https://doi.org/10.5194/os-8-433-2012 
Menezes, V. V., Macdonald, A.M., Schatzman, C., 2017. Accelerated freshening of Antarctic Bottom Water over the last decade in the Southern Indian Ocean. Sci. Adv. 3, 1-10. https://doi.org/10.1126/sciadv.1601426

Morales Maqueda, M.A., Willmott, A.J., Biggs, N.R.T., 2004. Polynya Dynamics: a Review of Observations and Modeling. Rev. Geophys. 42, RG1004. https://doi.org/10.1029/2002RG000116

Muench, D., Gordon, L., 1995. Circulation and transport of water along the western Weddell Sea margin. J. Geophys. Res. 100, 18503-18515.

Muench, R., Padman, L., Gordon, A., Orsi, A., 2009. A dense water outflow from the Ross Sea, Antarctica: Mixing and the contribution of tides. J. Mar. Syst. 77, 369-387. https://doi.org/10.1016/j.jmarsys.2008.11.003

Muench, R.D., Wåhlin, A.K., Özgökmen, T.M., Hallberg, R., Padman, L., 2009. Impacts of bottom corrugations on a dense Antarctic outflow: NW Ross Sea. Geophys. Res. Lett. 36, 1-6. https://doi.org/10.1029/2009GL041347

Nakano, H., Suginohara, N., 2002. Importance of the eastern Indian Ocean for the abyssal Pacific. J. Geophys. Res. Ocean. 107, 12-1-12-14. https://doi.org/10.1029/2001JC001065

Nicholls, K.W., Østerhus, S., Makinson, K., 2009. Ice-ocean processes over the continental shelf of the southern Weddell Sea, Antarctica: A review. Rev. Geophys. 47, 1-23. https://doi.org/10.1029/2007RG000250.1

Nihashi, S., Ohshima, K.I., 2015. Circumpolar mapping of antarctic coastal polynyas and landfast sea ice: Relationship and variability. J. Clim. 28, 3650-3670. https://doi.org/10.1175/JCLI-D-14-00369.1

Ohshima, K.I., Fukamachi, Y., Williams, G.D., Nihashi, S., Roquet, F., Kitade, Y., Tamura, T., Hirano, D., Herraiz-Borreguero, L., Field, I., Hindell, M., Aoki, S., Wakatsuchi, M., 2013. Antarctic Bottom Water production by intense sea-ice formation in the Cape Darnley polynya. Nat. Geosci. 6, 235-240. https://doi.org/10.1038/ngeo1738

Ohshima, K.I., Nihashi, S., Iwamoto, K., 2016. Global view of sea-ice production in polynyas and its linkage to dense/bottom water formation. Geosci. Lett. 3, 13. https://doi.org/10.1186/s40562-016-0045-4

Orsi, A.H., Johnson, G.C., Bullister, J.L., 1999. Circulation, mixing, and production of Antarctic Bottom Water. Prog. Oceanogr. 43, 55-109. https://doi.org/10.1016/S0079-6611(99)00004-X

Orsi, A.H., Smethie, W.M., Bullister, J.L., 2002. On the total input of Antarctic waters to the deep ocean : A preliminary estimate from chlorofluorocarbon measurements. J. Geophys. Res. 107, 1-17. https://doi.org/10.1029/2001JC000976

Padman, L., Howard, S.L., Orsi, A.H., Muench, R.D., 2009. Tides of the northwestern Ross Sea and their impact on dense outflows of Antarctic Bottom Water. Deep Sea Res. Part II Top. Stud. Oceanogr. 56, $818-834$.

Paolo, F.S., Fricker, H.A., Padman, L., 2015. Volume loss from Antarctic ice shelves is accelerating 348, $327-331$.

Pritchard, H.D., Ligtenberg, S.R.M., Fricker, H.A., Vaughan, D.G., van den Broeke, M.R., Padman, L., 2012. Antarctic ice-sheet loss driven by basal melting of ice shelves. Nature 484, 502-505. https://doi.org/10.1038/nature10968

Purkey, S.G., Johnson, G.C., 2010. Warming of global abyssal and deep Southern Ocean waters between the 1990s and 2000s: Contributions to global heat and sea level rise budgets. J. Clim. 23, 6336-6351. https://doi.org/10.1175/2010JCLI3682.1

Randall-Goodwin, E., Meredith, M.P., Jenkins, A., Yager, P.L., Sherrell, R.M., Abrahamsen, E.P., Guerrero, R., Yuan, X., Mortlock, R.A., Gavahan, K., Alderkamp, A.-C., Ducklow, H., Robertson, R., Stammerjohn, S.E., 2015. Freshwater distributions and water mass structure in the Amundsen Sea 
Polynya region, Antarctica. Elem. Sci. Anthr. 3, 000065. https://doi.org/10.12952/journal.elementa.000065

Rignot, E., Jacobs, S., Mouginot, J., Scheuchl, B., 2013. Ice-shelf melting around Antarctica. Science (80-. ). 341, 266-70. https://doi.org/10.1126/science.1235798

Rintoul, S.R., 1998. On the origin and influence of Adélie Land Bottom Water. Ocean. Ice, Atmos. interactins Antarct. Cont. margin 75, 151-171. https://doi.org/10.1029/AR075p0151

Rintoul, S.R., Silvano, A., Pena-Molino, B., van Wijk, E., Rosenberg, M., Greenbaum, J.S., Blankenship, D.D., 2016. Ocean heat drives rapid basal melt of the Totten Ice Shelf. Sci. Adv. 2, 1-6. https://doi.org/10.1126/sciadv.1601610

Seabrooke, J.M., Hufford, G.L., Elder, R.B., 1971. Formation of Antarctic bottom water in the Weddell Sea. J. Geophys. Res. Ocean. Atmos. 76, 2164-2178. https://doi.org/10.1029/JC076i009p02164

Shadwick, E.H., Rintoul, S.R., Tilbrook, B., Williams, G.D., Young, N., Fraser, A.D., Marchant, H., Smith, J., Tamura, T., 2013. Glacier tongue calving reduced dense water formation and enhanced carbon uptake. Geophys. Res. Lett. 40, 904-909. https://doi.org/10.1002/grl.50178

Shapiro, G.I., 2003. Dense water cascading off the continental shelf. J. Geophys. Res. 108, 1-19. https://doi.org/10.1029/2002JC001610

Silvano, A., Rintoul, S.R., Peña-Molino, B., Williams, G.D., 2017. Distribution of watermasses and meltwater on the continental shelf near the Totten and Moscow University ice shelves. J. Geophys. Res. Ocean. 122, 2050-2068. https://doi.org/10.1002/2016JC012115.Received

Smith, J.A., Hillenbrand, C.D., Pudsey, C.J., Allen, C.S., Graham, A.G.C., 2010. The presence of polynyas in the Weddell Sea during the Last Glacial Period with implications for the reconstruction of sea-ice limits and ice sheet history. Earth Planet. Sci. Lett. 296, 287-298. https://doi.org/10.1016/j.epsl.2010.05.008

Smith Jr, W., Sedwick, P., Arrigo, K.R., Ainley, D., Orsi, a. H., 2012. The Ross Sea in a Sea of Change. Oceanography 25, 90-103. https://doi.org/http://dx.doi.org/10.5670/oceanog.2012.80

Snow, K., Rintoul, S.R., Sloyan, B.M., Hogg, A.M.C., 2018. Change in Dense Shelf Water and Adélie Land Bottom Water Precipitated by Iceberg Calving. Geophys. Res. Lett. 45, 2380-2387. https://doi.org/10.1002/2017GL076195

Snow, K., Sloyan, B.M., Rintoul, S.R., Hogg, A.M.C., Downes, S.M., 2016. Controls on circulation, crossshelf exchange, and dense water formation in an Antarctic polynya. Geophys. Res. Lett. 43, 7089-7096. https://doi.org/10.1002/2016GL069479

Stewart, A.L., Thompson, A.F., 2015. Eddy-mediated transport of warm Circumpolar Deep Water across the Antarctic Shelf Break. Geophys. Res. Lett. 42, 432-440. https://doi.org/10.1002/2014GL062281

Tamura, T., Ohshima, K.. I., Nihashi, S., 2008. Mapping of sea ice production for Antarctic coastal polynyas. Geophys. Res. Lett. 35, L07606. https://doi.org/10.1029/2007GL032903

Tamura, T., Ohshima, K.I., Fraser, A.D., Williams, G.D., 2016. Sea ice production variability in Antarctic coastal polynyas. J. Geophys. Res. Ocean. 121, 2967-2979. https://doi.org/10.1002/2015JC011537

Thoma, M., Jenkins, A., Holland, D., Jacobs, S., 2008. Modelling Circumpolar Deep Water intrusions on the Amundsen Sea continental shelf, Antarctica. Geophys. Res. Lett. 35, 2-7. https://doi.org/10.1029/2008GL034939

Trumbore, S.E., Jacobs, S.S., Smethie, W.M., 1991. Chlorofluorocarbon evidence for rapid ventilation of the Ross Sea. Deep Sea Res. Part A, Oceanogr. Res. Pap. 38, 845-870. https://doi.org/10.1016/01980149(91)90022-8

Visbeck, M., Thurnherr, A.M., 2009. High-resolution velocity and hydrographic observations of the Drygalski Trough gravity plume. Deep Sea Res. Part II Top. Stud. Oceanogr. 56, 835-842. 
https://doi.org/10.1016/j.dsr2.2008.10.029

Walker, D.P., Brandon, M.A., Jenkins, A., Allen, J.T., Dowdeswell, J.A., Evans, J., 2007. Oceanic heat transport onto the Amundsen Sea shelf through a submarine glacial trough. Geophys. Res. Lett. 34, 2-5. https://doi.org/10.1029/2006GL028154

Walker, D.P., Jenkins, A., Assmann, K.M., Shoosmith, D.R., Brandon, M.A., 2013. Oceanographic observations at the shelf break of the Amundsen Sea, Antarctica. J. Geophys. Res. Ocean. 118, 29062918. https://doi.org/10.1002/jgrc. 20212

Webber, B.G.M., Heywood, K.J., Stevens, D.P., Dutrieux, P., Abrahamsen, E.P., Jenkins, A., Jacobs, S.S., Ha, H.K., Lee, S.H., Kim, T.W., 2017. Mechanisms driving variability in the ocean forcing of Pine Island Glacier. Nat. Commun. 8, 1-8. https://doi.org/10.1038/ncomms14507

Weijer, W., Veneziani, M., Stössel, A., Hecht, M.W., Jeffery, N., Jonko, A., Hodos, T., Wang, H., 2017. Local atmospheric response to an open-ocean polynya in a high-resolution climate model. J. Clim. 30, 1629-1641. https://doi.org/10.1175/JCLI-D-16-0120.1

Whitworth, I., Orsi, A.H., 2006. Antarctic Bottom Water production and export by tides in the Ross Sea. Geophys. Res. Lett. 33, 1-4. https://doi.org/10.1029/2006GL026357

Williams, G.D., Aoki, S., Jacobs, S.S., Rintoul, S.R., Tamura, T., Bindoff, N.L., 2010. Antarctic bottom water from the Adélie and George v Land Coast, East Antarctica (140-149 ${ }^{\circ}$ E). J. Geophys. Res. Ocean. 115, 1-29. https://doi.org/10.1029/2009JC005812

Williams, G.D., Bindoff, N.L., Marsland, S.J., Rintoul, S.R., 2008. Formation and export of dense shelf water from the Adélie depression, East Antarctica. J. Geophys. Res. Ocean. 113, 1-12. https://doi.org/10.1029/2007JC004346

Williams, G.D., Herraiz-Borreguero, L., Roquet, F., Tamura, T., Ohshima, K.I., Fukamachi, Y., Fraser, A.D., Gao, L., Chen, H., McMahon, C.R., Harcourt, R., Hindell, M., 2016. The suppression of Antarctic bottom water formation by melting ice shelves in Prydz Bay. Nat. Commun. 7, 12577. https://doi.org/10.1038/ncomms12577

Yabuki, T., Suga, T., Hanawa, K., Matsuoka, K., Kiwada, H., Watanabe, T., 2006. Possible source of the antarctic bottom water in the Prydz Bay Region. J. Oceanogr. 62, 649-655.

https://doi.org/10.1007/s10872-006-0083-1 


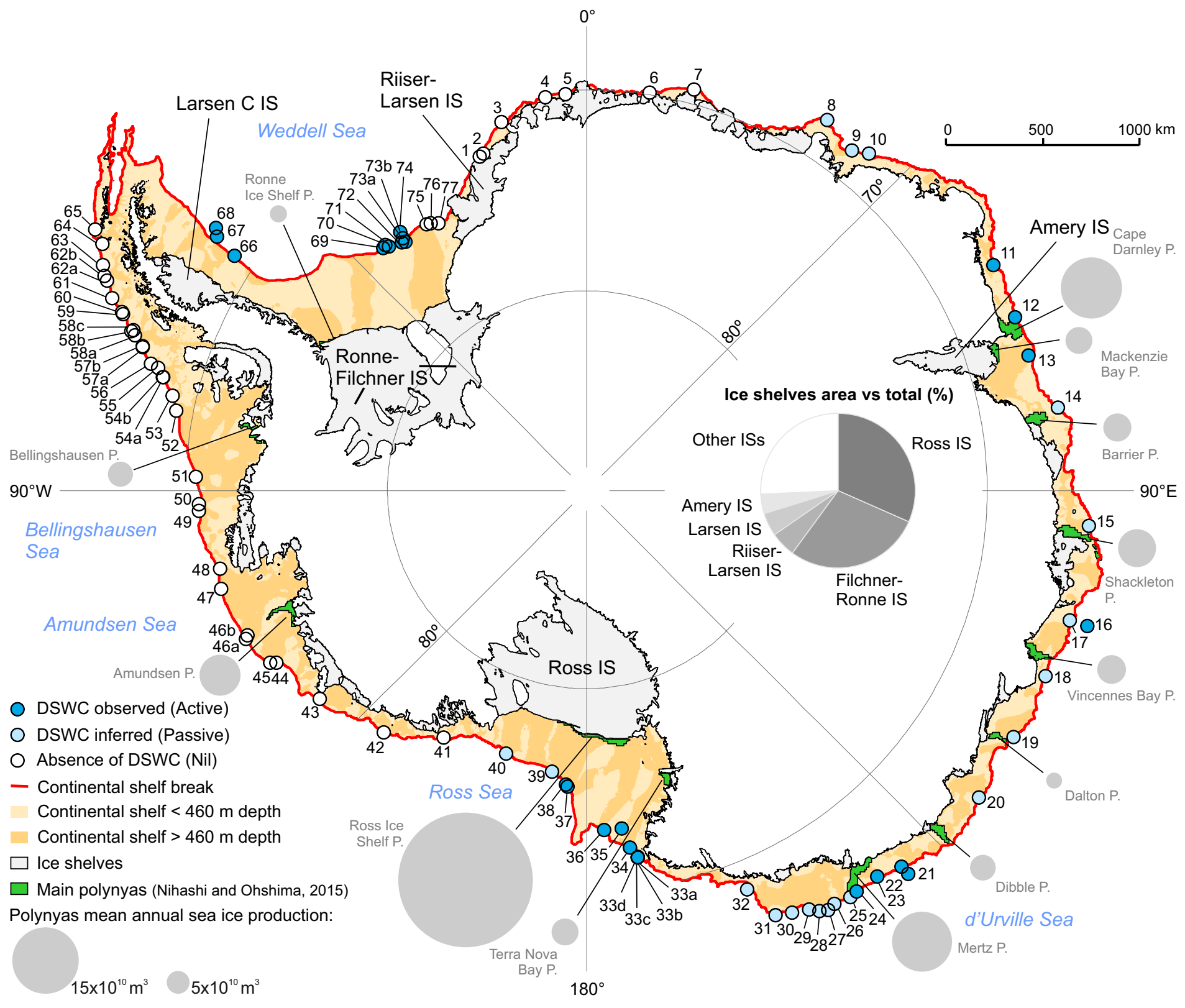

Figure 1 


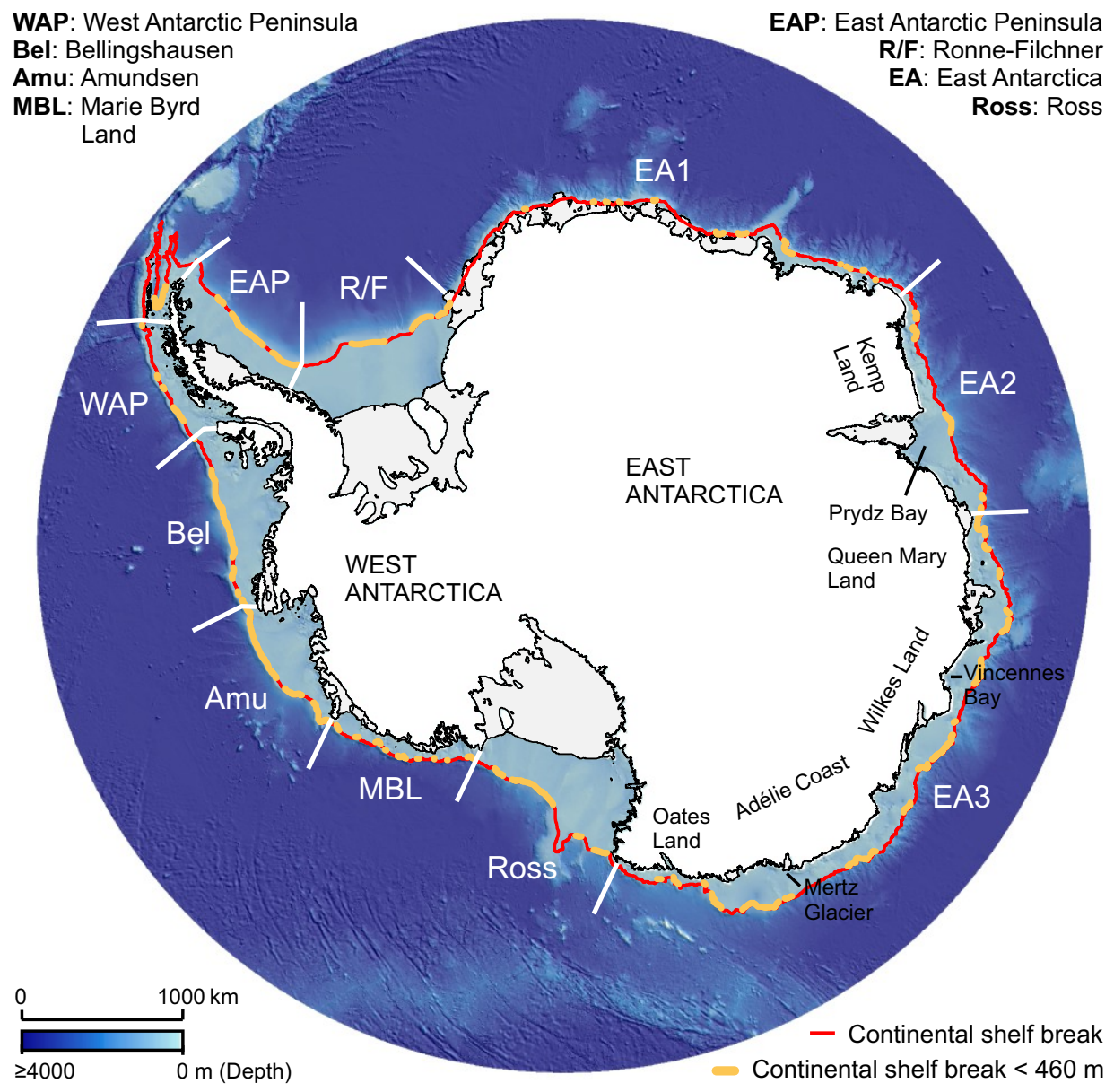

Figure 2 


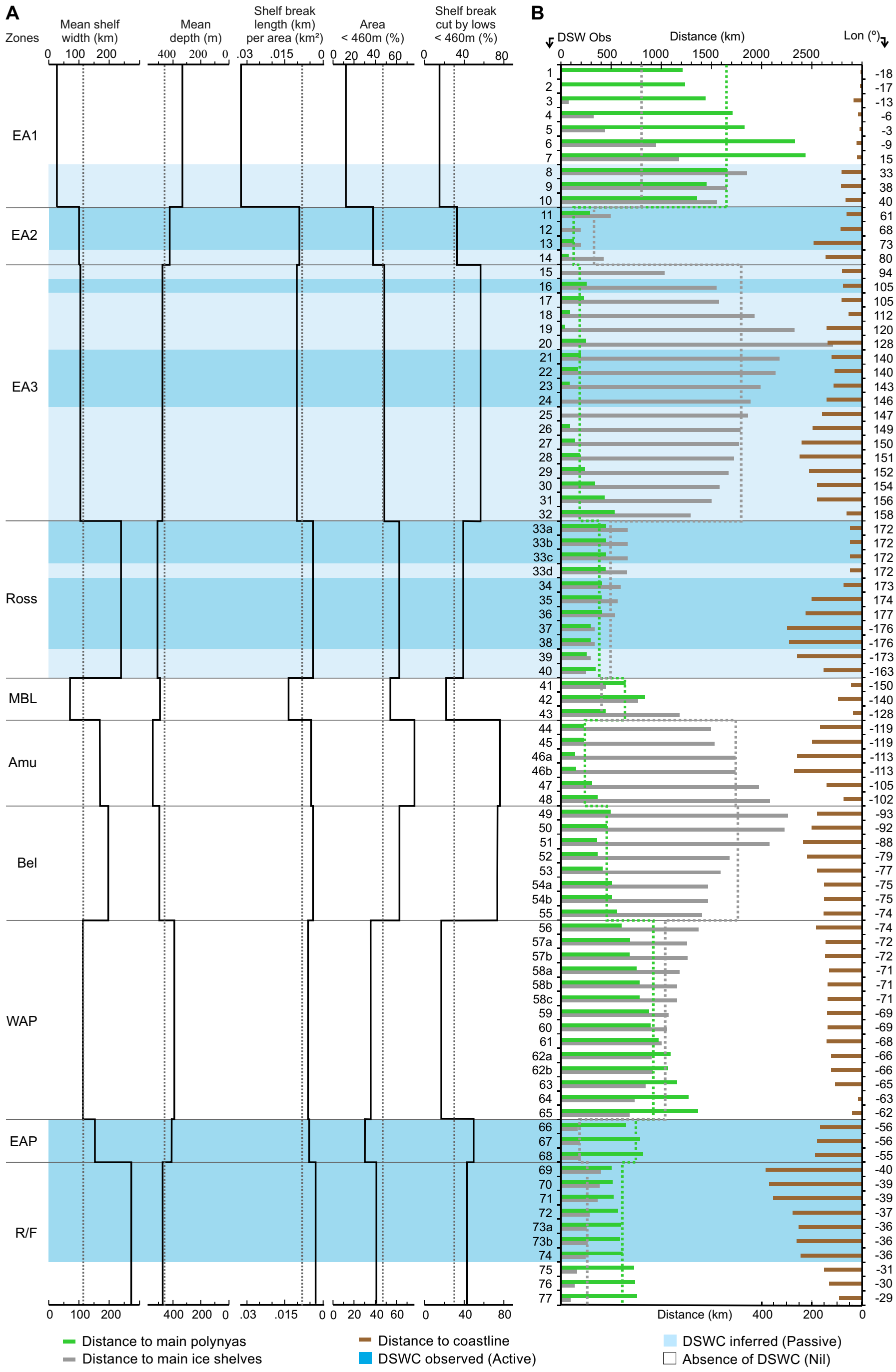

Figure 3 


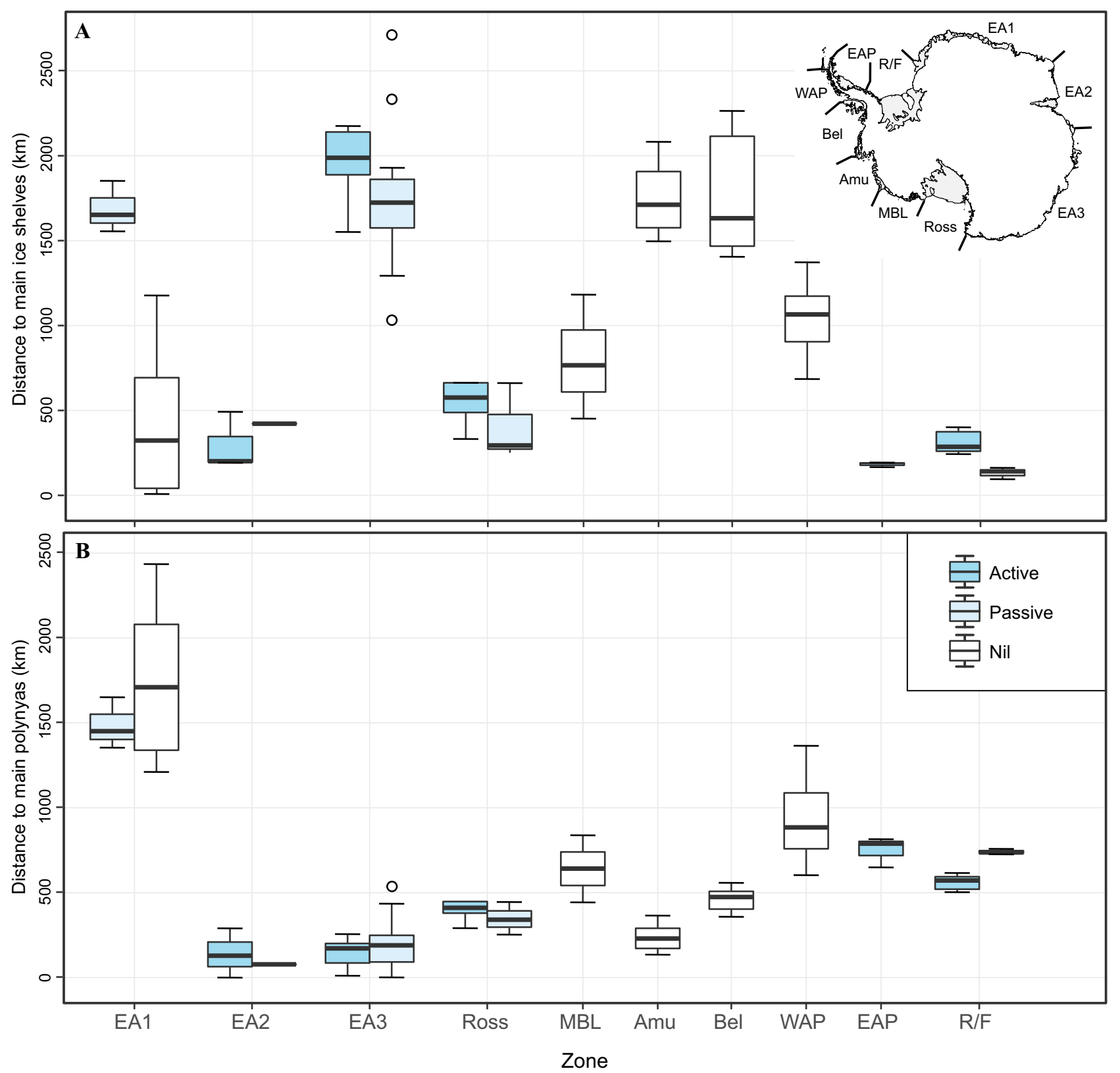

Figure 4 

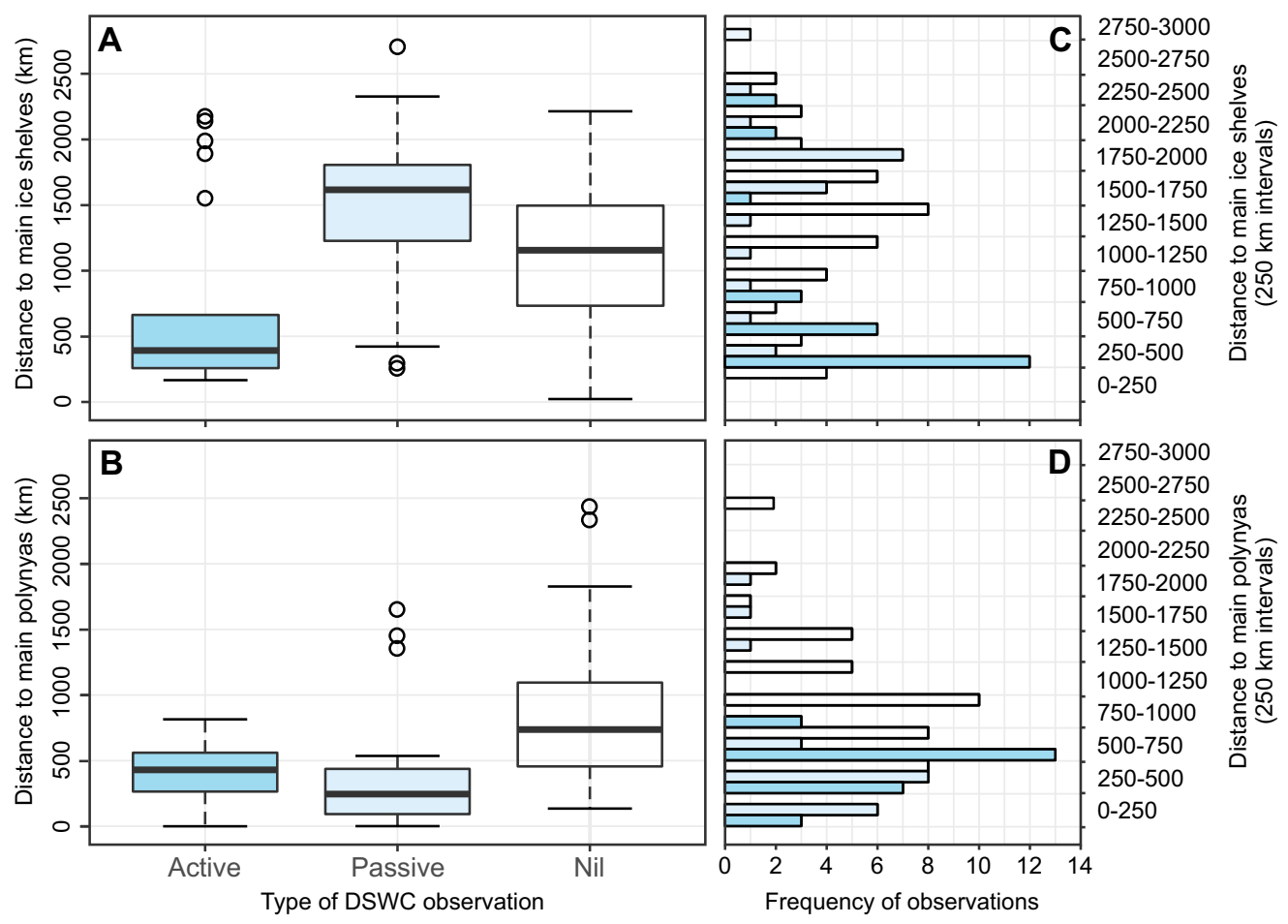

Figure 5 


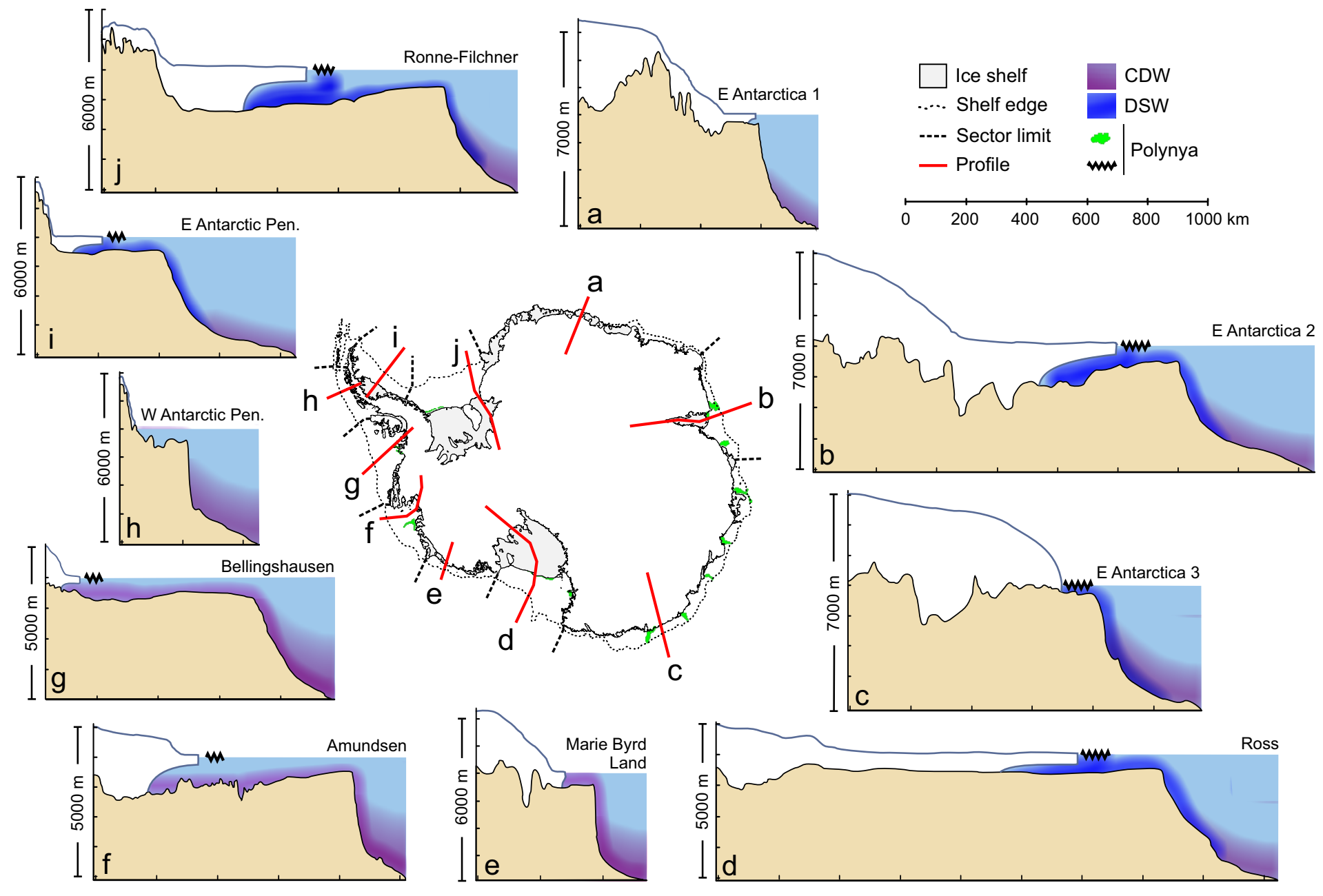

Figure 6 


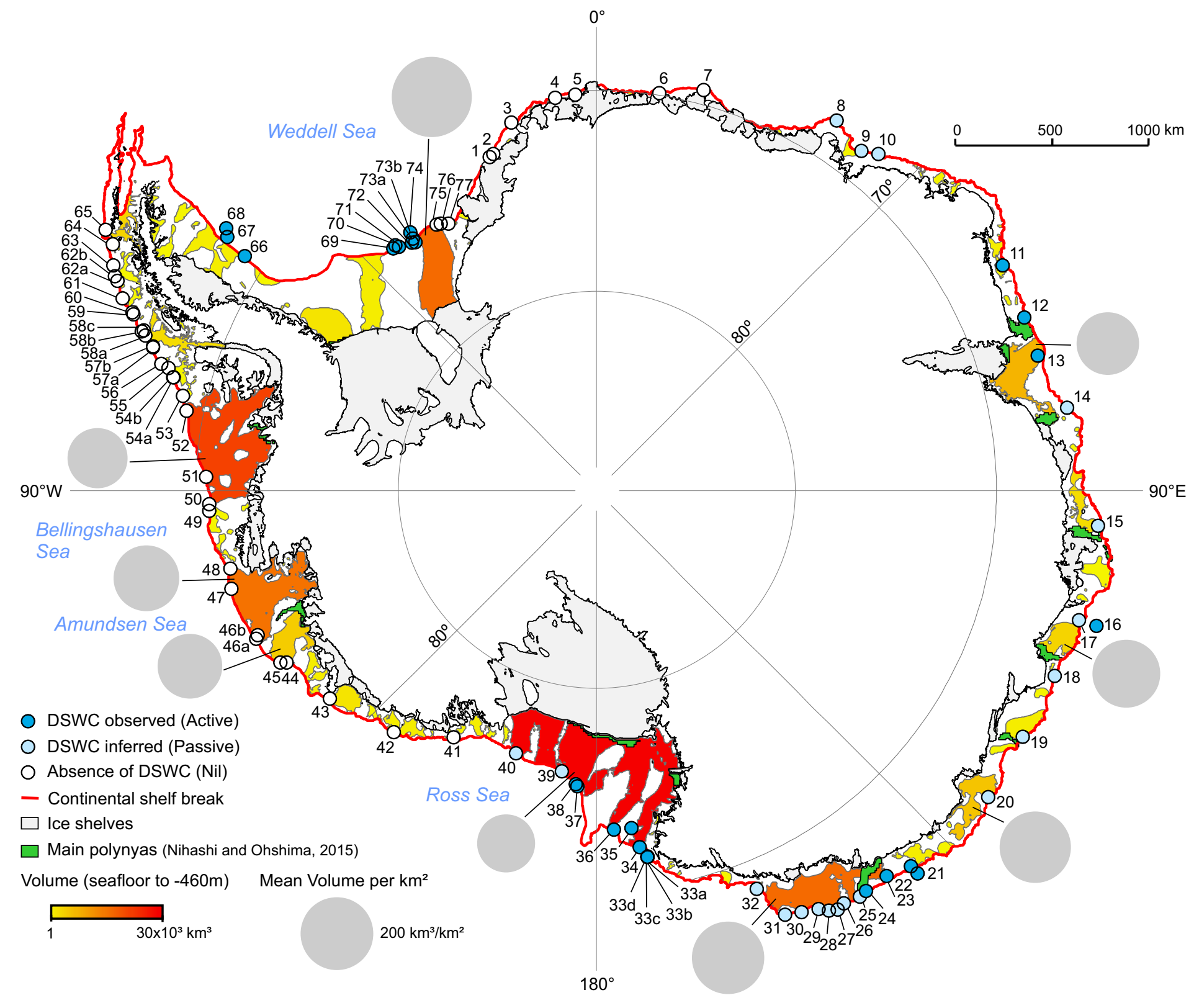

Supplementary Figure 1 

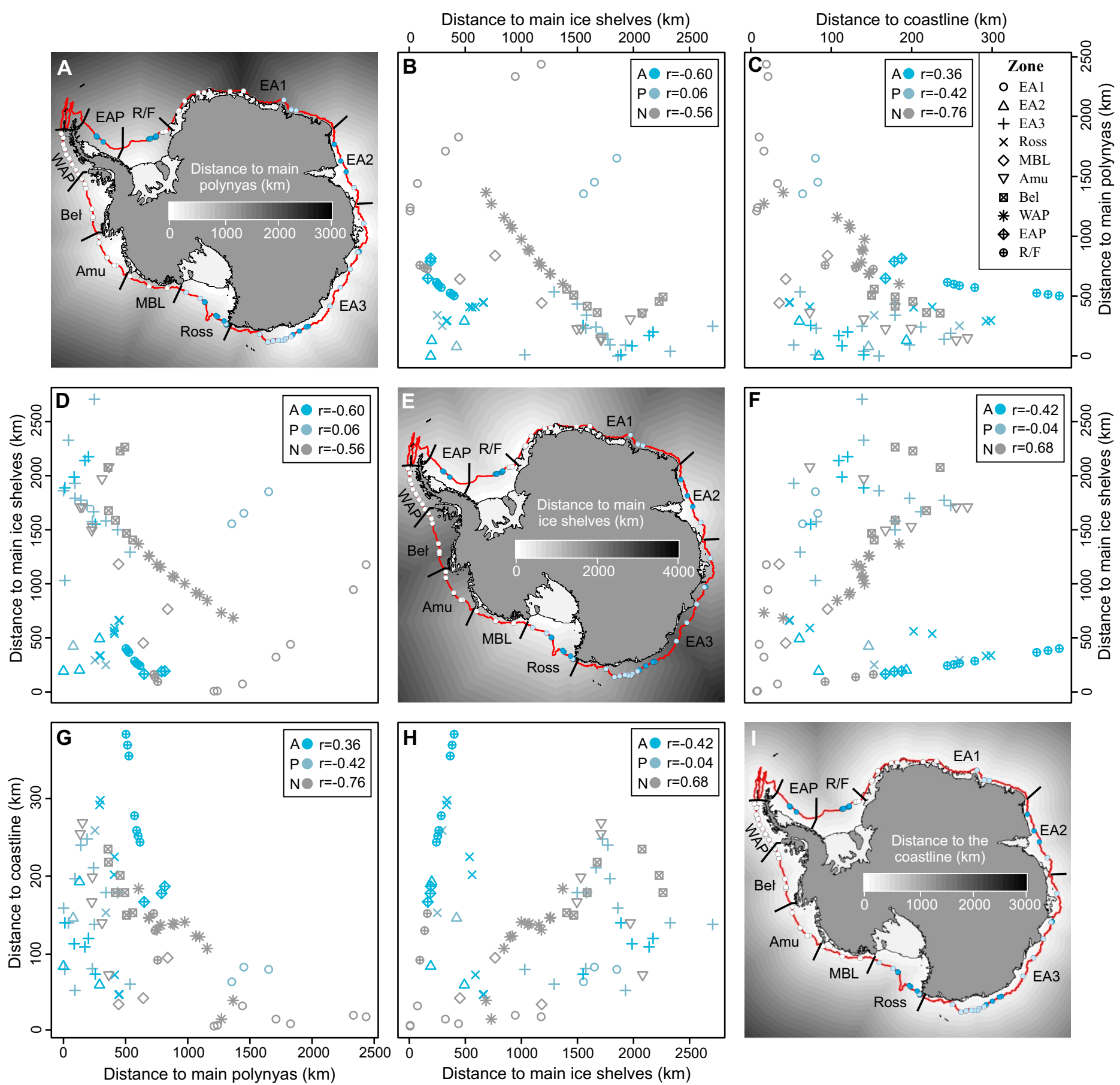

Supplementary Figure 2 